\title{
Efficiency of Potted Plants in Maintaining the Quality of Indoor Air
}

\author{
Shraranbir Kaur Bal*, Jatinderjit Kaur Gill and Akriti Sharma \\ Department of Family Resource Management, College of Home Science, India
}

Corresponding author

\begin{tabular}{|l|}
\hline Key w or d s \\
Indoor \\
environment, \\
Humidity, \\
Temperature, \\
Objective \\
assessment
\end{tabular}

A B S T R A C T
Indoor environments contribute significantly to total human exposure to air pollutants, as people spend most of their time indoors. Indoor air quality is influenced by penetrating outdoor air, specific indoor pollution sources, interactions between building system/construction techniques and occupants. Some pollutants may be 2-5 times more concentrated inside than outside buildings . Since people spend most of their time indoors, so the quality of indoor air has major implications for health and can contribute to a wide spectrum of respiratory health effects, from allergic sensitization to cancer. Natural pollutants such as allergens, dampness and mould and radon can also have significant health effects. Reflecting the complexity of indoor pollution, the most effective ways to reduce its impact are home based, multi component interventions. Research shows that many common houseplants and blooming potted plants can improve inmates health by helping to fight these pollutants in the home. While it's common knowledge that plants absorb carbon dioxide and release oxygen as part of photosynthesis, research by the National Aeronautics and Space Administration (NASA) also confirmed that plants eliminate harmful gases from the air. So looking into the importance of plants in our lives, the study was planned out to assess the role of selected plants in improving indoor environment. Results indicated that in all the rooms where indoor plants were placed showed improvement in air quality both in the case of carbon-di-oxide where majority of the houses lie in limit 501-999 ppm and in case of Carbon-monoxide majority of the houses lie in limit $0-3.5 \mathrm{ppm}$. All the areas showed that both the gases were well within the permissible limit (permissible limit $1000 \mathrm{ppm}$ for carbon-dioxide whereas permissible limit 9ppm for carbon-monoxide). Further, in all the rooms where indoor plants were placed showed improvement in humidity level where majority of the houses had humidity limit above permissible limit of $60 \%$ and temperature limit above $24^{\circ} \mathrm{C}$ respectively.

\section{Introduction}

The indoor environment affects comfort, health, and productivity. People spend most of their time indoors, so most of the adverse exposures that they encounter regularly take place indoors. Many exposures that are potentially hazardous to health are exposures to substances emitted indoors from indoor sources. Such emissions can occur from building materials; from products used or stored indoors; from processes that occur in indoor environments; from the microorganisms, insects, other animals, and plants 
that live indoors; and from the behavior of building occupants. Because of the contributions from indoor sources, indoor levels of many pollutants are higher than those found outdoors.

According to the National Institute of Occupational Safety and Health, concentration of $\mathrm{CO}_{2}$ that exceeds $1,000 \mathrm{ppm}$ is a marker of inadequate ventilation which is by far the largest cause of IAP. Indoor air quality is effected by concentrations of outdoor air pollutants, indoor sources of contamination e.g. combustion of solid fuels, biomass fuels, coal, kerosene, etc. building materials and habits of residents.(Singh 2015) As polluted outdoor air moves indoors, it mixes with more indoor contaminants from unflawed gas appliances and VOCs out-gassing from plastic, synthetic furnishings, finishes, solvents, etc.

The use of plants for indoor comfort has been actively suggested since the research on green building design has been widely conducted to provide an environmentally sound space inside and outside buildings. In addition to the function of being just ornamentation, indoor plants have an improved effect on the indoor environment such as the reduction of indoor pollutants, the adequate control of temperature and humidity, the purification and filtering of polluted air, and the insulation of noise. In this connection woman being the key person of the family, can take initiative in showing concern about the control of pollution with proper use and placement of appropriate plants indoors and can play a vital role in this aspect. The present research was thus planned with the objective of studying the impact of house plants on the quality of indoor air.

\section{Materials and Methods}

The study was conducted in two randomly selected zones of Ludhiana city.

\section{Selection of zones}

For the selection of the zones, out of four zones of Ludhiana city, two zones (zone-D and zone-B) were randomly selected and from the selected zones three localities were further selected randomly.

\section{Selection of respondents}

For the selection of the respondents, from each randomly selected locality, 20 respondents living in 300 square yards and east facing houses were selected purposively thus making a total sample of 120. Further from the selected houses, four different rooms i,e. living room, bedroom room, drawing room and kitchen having approximately equal floor area, window and door areas were used for placing selected groups of plants.

House plants which were commonly placed indoors were categorised under four subgroups i.e. Common plants, Broad leaved plants, Broad leaved + Succulents and Succulents. One plant from each group was selected and thus placed at suitable locations in different rooms for five days. The plants under these groups were selected according to their frequency of occurrence in the surveyed houses already done and availability in PAU as well as local nurseries.

To study the impact of house plants on indoor environment, objective assessment was undertaken before (pre test) and after placing the plants (post test) in different rooms, for which 'Air Quality Monitor' was used to assess the level of carbon-di-oxide, and carbon-monoxide in the rooms. The relative humidity in the air was measured using the hygrometer and Thermometer was used to observe the temperature inside the different rooms. The results were analyzed by using various statistical tools. 


\section{Results and Discussion}

The results obtained from the field experiments and relevant discussion have been given below:-

\section{Objective assessment of carbon dioxide}

Table 1 contains the data on the concentrations of $\mathrm{CO}_{2}$ before and after placing selected group of plants, in four different areas(living room, bedroom, kitchen and drawing room) of the house of the respondents. The mean values of $\mathrm{CO}_{2}$ for the rooms with and without houseplants were 787.94 ppm, $645.67 \mathrm{ppm}, 925.69 \mathrm{ppm}$, $657.42 \mathrm{ppm}$ and $777.91 \mathrm{ppm}, 623.76 \mathrm{ppm}$, $920.67 \mathrm{ppm}, 645.34 \mathrm{ppm}$ respectively. When these values of $\mathrm{CO}_{2}$ were statistically analysed, no significant difference was found in plants. It also showed that the concentration of $\mathrm{CO}_{2}$ was non-significant. However, the mean values do indicate that the concentration of $\mathrm{CO}_{2}$ in the rooms was always higher than the one in the room with plants.

Table further explains that maximum residences $(73.33 \%)$ were found to have $\mathrm{CO}_{2}$ limit between 501-999 ppm in their living room in pre-test whereas 56.67 per cent of living area in post test were found to be having $\mathrm{CO}_{2}$ concentration in this range. However, the concentration of $\mathrm{CO}_{2}$ range lies between 501-999 ppm in majority $(56.67 \%)$ of the houses in pre-test as compared to posttest $(48.33 \%)$ in case of bedrooms. The Concentration of $\mathrm{CO}_{2}$ in different rooms was observed to be well within the safe limits as permissible limit of $\mathrm{CO}_{2}$ in atmosphere is $1000 \mathrm{ppm}$ as recommended by Occupational Safety \& Health Administration (OSHA) as well as American Society of Heating, Refrigerating and Air Conditioning Engineers (ASHRAE).

It can further be seen from the table that $\mathrm{CO}_{2}$ in the kitchens was higher $(60.00 \%)$ in pre-test again in the range of 501-999 ppm in comparison with post test $(51.66 \%)$. It can also be seen in the table that the $\mathrm{CO}_{2}$ concentration in the drawing rooms in pre-test were in majority $(66.77 \%)$ and lies in the range of 501$999 \mathrm{ppm}$ as compared to post-test(55.83\%). Raza et al. (1991) have reported that certain plants, have the capacity of removing atmospheric $\mathrm{CO}_{2}$ even during night time. The authors proposed the use of selected house plants in controlling $\mathrm{CO}_{2}$ concentration as an air pollutant. Considering the results of $\mathrm{CO}_{2}$ concentration in the rooms with and without plants, it appears that the house plants included in this study helped in maintaining lower concentration of $\mathrm{CO}_{2}$.

\section{Objective assessment of carbon monoxide (CO)}

Table 2 contained the data on the concentrations of $\mathrm{CO}$ before and after placing plants, in four different areas(living, bedroom, kitchen and drawing room ) of the house of the respondents. The mean values for the rooms with plants were (53.85), (55.67), (54.86), (58.46) and without plants were (57.9), (58.32), (48.26), (52.02) respectively. It further showed that the concentration of $\mathrm{CO}$ was highly significant. However, the mean values do indicate that the concentration of $\mathrm{CO}$ in the rooms without plants were always higher as compared to the one with plants.

Table 2 highlights that maximum residences $(70.00 \%)$ were found to have $\mathrm{CO}$ concentration between 0-3.5 ppm limit in pretest whereas in post-test i.e. after placing plants it was 66.67 per cent, as far as living area was concerned. Concentration of $\mathrm{CO}$ in majority (81.67\%) in bedroom for pre-test was within the limit of 0-3.5 ppm as in comparison with post-test which was 78.33 per cent. It is seen in Table 2, that $\mathrm{CO}$ concentration was higher $(53.33 \%)$ in houses in pre-test whereas in post-test $(50.83 \%)$ the concentration level was down. 
Table.1 Objective assessment of carbon dioxide in the houses of respondents

\begin{tabular}{|c|c|c|c|c|c|c|c|c|c|c|c|}
\hline \multirow{3}{*}{$\begin{array}{l}\text { Objective } \\
\text { parameter }\end{array}$} & \multirow{2}{*}{\multicolumn{5}{|c|}{ Pre-test (without plants) }} & \multirow{2}{*}{\multicolumn{5}{|c|}{ Post-test (with plants) }} & \multirow[b]{3}{*}{$\mathrm{t}$ value } \\
\hline & & & & & & & & & & & \\
\hline & $\begin{array}{l}\text { Below } \\
\text { 500ppm }\end{array}$ & $\begin{array}{l}\text { 501- } \\
\text { 999ppm }\end{array}$ & $\begin{array}{l}\text { Above } \\
\text { 1000ppm }\end{array}$ & Mean & SD & $\begin{array}{l}\text { Below } \\
\text { 500ppm }\end{array}$ & $\begin{array}{l}\text { 501- } \\
\text { 999ppm }\end{array}$ & $\begin{array}{l}\text { Above } \\
\text { 1000ppm }\end{array}$ & Mean & SD & \\
\hline Living & $\begin{array}{c}10 \\
(8.33)\end{array}$ & $\begin{array}{c}88 \\
(73.33)\end{array}$ & $\begin{array}{c}22 \\
(18.33)\end{array}$ & 787.94 & 298.78 & $\begin{array}{c}40 \\
(33.33)\end{array}$ & $\begin{array}{c}68 \\
(56.67)\end{array}$ & $\begin{array}{c}12 \\
(10.00)\end{array}$ & 777.91 & 294.76 & 0.24 \\
\hline Bed Room & $\begin{array}{c}22 \\
(18.33)\end{array}$ & $\begin{array}{c}68 \\
(56.67)\end{array}$ & $\begin{array}{c}30 \\
(25.00)\end{array}$ & 645.67 & 117.54 & $\begin{array}{c}42 \\
(35.00)\end{array}$ & $\begin{array}{c}58 \\
(48.33)\end{array}$ & $\begin{array}{c}20 \\
(16.67)\end{array}$ & 623.76 & 111.45 & $1.35^{*}$ \\
\hline Kitchen & $\begin{array}{c}20 \\
(16.67)\end{array}$ & $\begin{array}{c}72 \\
(60.00)\end{array}$ & $\begin{array}{c}28 \\
(23.33)\end{array}$ & 925.69 & 425.67 & $\begin{array}{c}40 \\
(33.33)\end{array}$ & $\begin{array}{c}62 \\
(51.66)\end{array}$ & $\begin{array}{c}18 \\
(15.00)\end{array}$ & 920.67 & 416.57 & 0.08 \\
\hline $\begin{array}{l}\text { Drawing } \\
\text { Room }\end{array}$ & $\begin{array}{c}20 \\
(16.67)\end{array}$ & $\begin{array}{c}80 \\
(66.67)\end{array}$ & $\begin{array}{c}20 \\
(16.67)\end{array}$ & 657.42 & 92.05 & $\begin{array}{c}42 \\
(35.00)\end{array}$ & $\begin{array}{c}67 \\
(55.83)\end{array}$ & $\begin{array}{c}11 \\
(9.17)\end{array}$ & 645.34 & 96 & 0.9 \\
\hline
\end{tabular}

\section{Multiple responses}

Figures in parentheses indicate percentages

*Significant $5 \%$ level

Table.2 Objective assessment of carbon monoxide in the houses of respondents

$$
\mathrm{n}=120
$$

\begin{tabular}{|c|c|c|c|c|c|c|c|c|c|c|c|}
\hline \multirow[b]{3}{*}{$\begin{array}{l}\text { Objective } \\
\text { parameters }\end{array}$} & \multirow{2}{*}{\multicolumn{5}{|c|}{ Pre-test (without plants) }} & \multirow{2}{*}{\multicolumn{5}{|c|}{ Post-test (with plants) }} & \multirow[b]{3}{*}{ t value } \\
\hline & & & & & & & & & & & \\
\hline & $0-3.5 \mathrm{ppm}$ & 3.6-8 ppm & $\begin{array}{l}\text { Above } \\
9 \mathrm{ppm}\end{array}$ & Mean & SD & $0-3.5 \mathrm{ppm}$ & $3.6-8 \mathrm{ppm}$ & $\begin{array}{l}\text { Above } \\
9 \mathrm{ppm}\end{array}$ & Mean & SD & \\
\hline Living & $\begin{array}{c}84 \\
(70.00)\end{array}$ & $\begin{array}{c}20 \\
(16.67)\end{array}$ & $\begin{array}{c}16 \\
(13.33)\end{array}$ & 57.9 & 11.83 & $\begin{array}{c}80 \\
(66.67)\end{array}$ & $\begin{array}{c}22 \\
(18.33)\end{array}$ & $\begin{array}{c}18 \\
(15.00)\end{array}$ & 53.85 & 12.12 & $2.39 *$ \\
\hline Bed Room & $\begin{array}{c}98 \\
(81.67)\end{array}$ & $\begin{array}{c}15 \\
(12.5)\end{array}$ & $\begin{array}{c}7 \\
(5.83)\end{array}$ & 58.32 & 11.54 & $\begin{array}{c}94 \\
(78.33)\end{array}$ & $\begin{array}{c}22 \\
(18.33)\end{array}$ & $\begin{array}{c}4 \\
(3.33)\end{array}$ & 55.67 & 10.67 & 1.68 \\
\hline Kitchen & $\begin{array}{c}64 \\
(53.33)\end{array}$ & $\begin{array}{c}44 \\
(36.67)\end{array}$ & $\begin{array}{c}12 \\
(10.00)\end{array}$ & 48.26 & 10.31 & $\begin{array}{c}61 \\
(50.83)\end{array}$ & $\begin{array}{c}59 \\
(49.17)\end{array}$ & $\begin{array}{c}0 \\
(0.00)\end{array}$ & 54.86 & 11.16 & $4.34 * *$ \\
\hline Drawing Room & $\begin{array}{c}81 \\
(67.5)\end{array}$ & $\begin{array}{c}25 \\
(20.83)\end{array}$ & $\begin{array}{c}14 \\
(11.67)\end{array}$ & 52.02 & 8.18 & $\begin{array}{c}94 \\
(78.33)\end{array}$ & $\begin{array}{c}20 \\
(16.67)\end{array}$ & $\begin{array}{c}6 \\
(5.00)\end{array}$ & $58 . .46$ & 12.26 & $4.36 * *$ \\
\hline
\end{tabular}

Multiple responses

Figures in parentheses indicate percentages

*Significant $5 \%$ level

**Significant $1 \%$ level 
Table.3 Objective assessment of relative humidity in the houses of respondents

\begin{tabular}{|c|c|c|c|c|c|c|c|c|c|c|c|}
\hline \multirow{3}{*}{$\begin{array}{l}\text { Objective } \\
\text { parameters }\end{array}$} & \multirow{2}{*}{\multicolumn{5}{|c|}{ Pre-test (without plants) }} & \multirow{2}{*}{\multicolumn{5}{|c|}{ Post-test (with plants) }} & \multirow{3}{*}{$\frac{20}{\mathrm{t} \text { value }}$} \\
\hline & & & & & & & & & & & \\
\hline & Below $40 \%$ & $41-60 \%$ & Above $60 \%$ & Mean & SD & Below $40 \%$ & $41-60 \%$ & Above $60 \%$ & Mean & SD & \\
\hline Living & $\begin{array}{c}24 \\
(20.00)\end{array}$ & $\begin{array}{c}36 \\
(30.00)\end{array}$ & $\begin{array}{c}60 \\
(50.00)\end{array}$ & 58.5 & 14.36 & $\begin{array}{c}22 \\
(18.33)\end{array}$ & $\begin{array}{c}39 \\
(32.5)\end{array}$ & $\begin{array}{c}59 \\
(49.17)\end{array}$ & 57.9 & 11.83 & 0.32 \\
\hline Bed Room & $\begin{array}{c}22 \\
(18.33)\end{array}$ & $\begin{array}{c}42 \\
(35.00)\end{array}$ & $\begin{array}{c}56 \\
(46.67)\end{array}$ & 59.15 & 18.2 & $\begin{array}{c}20 \\
(16.67)\end{array}$ & $\begin{array}{c}46 \\
(38.33)\end{array}$ & $\begin{array}{c}54 \\
(45.00)\end{array}$ & 58.32 & 11.54 & 0.38 \\
\hline Kitchen & $\begin{array}{c}16 \\
(13.33)\end{array}$ & $\begin{array}{c}52 \\
(43.33)\end{array}$ & $\begin{array}{c}52 \\
(43.33)\end{array}$ & 58.77 & 15.95 & $\begin{array}{c}20 \\
(16.67)\end{array}$ & $\begin{array}{c}49 \\
(40.83)\end{array}$ & $\begin{array}{c}51 \\
(42.5)\end{array}$ & 48.26 & 10.31 & $5.53 * *$ \\
\hline Drawing Room & $\begin{array}{c}24 \\
(20.00)\end{array}$ & $\begin{array}{c}42 \\
(35.00)\end{array}$ & $\begin{array}{c}54 \\
(45.00)\end{array}$ & 57.17 & 17.86 & $\begin{array}{c}27 \\
(22.5)\end{array}$ & $\begin{array}{c}41 \\
(34.17)\end{array}$ & $\begin{array}{c}52 \\
(43.33)\end{array}$ & 52.02 & 8.18 & $2.61 * *$ \\
\hline
\end{tabular}

Multiple responses

Figures in parentheses indicate percentages

*Significant $5 \%$ level

**Significant $1 \%$ level

Table.4 Objective assessment of temperature in the houses of respondents

\begin{tabular}{|c|c|c|c|c|c|c|c|c|c|c|c|}
\hline \multirow[b]{3}{*}{$\begin{array}{l}\text { Objective } \\
\text { parameters }\end{array}$} & \multirow{2}{*}{\multicolumn{5}{|c|}{ Pre-test (without plants) }} & & & & & & $=120$ \\
\hline & & & & & & \multicolumn{5}{|c|}{ Post-test (with plants) } & \\
\hline & $\begin{array}{c}\text { Below } \\
22\end{array}$ & $22.1-24$ & Above 24 & Mean & SD & $\begin{array}{c}\text { Below } \\
22\end{array}$ & $22.1-24$ & Above 24 & Mean & SD & t value \\
\hline Living & $\begin{array}{c}0 \\
(0.00)\end{array}$ & $\begin{array}{c}0 \\
(0.00)\end{array}$ & $\begin{array}{c}120 \\
(100.00)\end{array}$ & 32.13 & 6.12 & $\begin{array}{c}0 \\
(0.00)\end{array}$ & $\begin{array}{c}0 \\
(0.00)\end{array}$ & $\begin{array}{c}120 \\
(100.00)\end{array}$ & 31.9 & 6.13 & $2.26^{*}$ \\
\hline Bed Room & $\begin{array}{c}0 \\
(0.00)\end{array}$ & $\begin{array}{c}0 \\
(0.00)\end{array}$ & $\begin{array}{c}120 \\
(100.00)\end{array}$ & 31.21 & 6.31 & $\begin{array}{c}0 \\
(0.00)\end{array}$ & $\begin{array}{c}0 \\
(0.00)\end{array}$ & $\begin{array}{c}120 \\
(100.00)\end{array}$ & 31.12 & 6.29 & 0.10 \\
\hline Kitchen & $\begin{array}{c}0 \\
(0.00)\end{array}$ & $\begin{array}{c}0 \\
(0.00)\end{array}$ & $\begin{array}{c}120 \\
(100.00)\end{array}$ & 34.44 & 4.68 & $\begin{array}{c}0 \\
(0.00)\end{array}$ & $\begin{array}{c}0 \\
(0.00)\end{array}$ & $\begin{array}{c}120 \\
(100.00)\end{array}$ & 34.67 & 4.67 & 0.34 \\
\hline Drawing Room & $\begin{array}{c}0 \\
(0.00)\end{array}$ & $\begin{array}{c}0 \\
(0.00)\end{array}$ & $\begin{array}{c}120 \\
(100.00)\end{array}$ & 32.87 & 5.31 & $\begin{array}{c}0 \\
(0.00)\end{array}$ & $\begin{array}{c}0 \\
(0.00)\end{array}$ & $\begin{array}{c}120 \\
(100.00)\end{array}$ & 32.5 & 5.29 & 0.49 \\
\hline
\end{tabular}

Multiple responses

Figures in parentheses indicate percentages

*Significant $5 \%$ level

**Significant $1 \%$ level 
It was thus found that $\mathrm{CO}$ level was found in majority $(67.5 \%)$ of houses in the limit of 0 $3.5 \mathrm{ppm}$ in the pre-test in contrast to post-test $(78.33 \%)$.

Wolvertonet al., (1989) reported that plants may reduce the level of air contaminants, including formaldehyde, benzene, trichloroethylene, carbon monoxide and nitrogen dioxide. Considering the results of carbon monoxide concentration in the rooms with and without plants, it appears that the house plants included in this study help in maintaining lower concentration of $\mathrm{CO}$.

\section{Objective assessment of relative humidity}

The results of the relative humidity(\%) levels both in rooms with and without plants in the four areas of the house have been presented in Table 3. The tabulated mean values indicated that the relative humidity was always higher in the rooms with plants as compared to the one without plants. When the results were statistically analyzed, it was observed that there were no significant difference between the values for the rooms with and without plants for parameters living and bed room. Whereas, parameters such as kitchen and drawing room with the same plants without plants were found to be significant.

High level of humidity hampers evaporation causes great discomfort, reduces work efficiency and gives rise to various types of fungus, algae and bacteria and virus that are harmful to the health of inmates.

The present study confirms the results already reported by Wolverton (1996), who had observed higher relative humidity in room filled with house plants as compared to a similar plant free room. The higher $\mathrm{RH}$ in a room with house plants might be attributed to the evaporation of moisture from the top soil of pots containing the plant as well as the transpiration losses of plant themselves. Based on the findings of the present study as well as studies reported by Asaumi et al., (1995) and Wolverton and Wolverton (1996), it may be concluded that house plants may be kept in rooms where higher levels of $\mathrm{RH}$ are required for achieving comfort zone for the inhabitants or reducing the number of air borne microbes as well as conservation of energy in the case of air conditional rooms.

\section{Objective assessment of temperature}

The results of the estimation of room temperature before and after placing plants, in four different areas(living, bedroom, kitchen and drawing room) of the house of the respondents have been presented in Table 4. When statistically analysed, results indicated that the temperature was significantly higher in the rooms without plants.

The difference of temperature was observed between the rooms with and without plants. The mean values of temperatures, indicate that the room temperatures in the rooms without houseplants were always higher (32.13), (31.21), (34.44), (32.87) in comparison to the rooms with house plants i.e. (31.9), (31.12), (34.67), (32.5) respectively.

Conclusively, it can be expressively denoted that house plants lowers the concentrations of carbon dioxide and carbon mono-oxide and also help maintain relative humidity and temperature levels, and they do have a positive impact on the household environment.

A woman or homemaker can use or have house plants without much expenditure in reducing the ill effects of indoor and outdoor environmental pollution. With little knowledge on their selection, placement and upkeep, plants can successfully be employed 
to play a functional, psychological, asthetic and decorative role in household conditions.

\section{References}

Chang C Y and Chen P K (2005) Human response to window views and indoor plants in the workplace. Hort Sci 40: 1354-59.

Chauhan C (2013) Indoor air pollution kills: A million people every year in India. Hindustan Times.com, Web: 9 April 2015.

Coleman C and R H Mattson (1995) Influences of foliage plants on human stress during thermal biofeedback training. Hort Technol 5: 137-40.

Khare M and Gupta S (2000) Indoor air pollution. J Irrish Assoc Emergency Medicine 27:103-10.

Kumari AK (2007) Evolution of environmental legislation in India. ICFAI University, Hyderabad. http://dx.doi.org/10.2139/ssrn.956228

Mullick PL (1984) Elements of home science. Kalyani Publishers, New Delhi.

Samet JM, Dominici F, Curriero FC, Coursac I and Zeger SL (2000) Fine particulate air pollution and mortality in 20 US cities. New England J Med 343: $1742-$ 49.

Wang $\mathrm{Z}$ and Zhang JS (2011) Characterization and performance of a full-scale activated carbon-based dynamic botanical air filtration system for improving indoor air quality. Build
Environ 46: 758-68.

Wolverton BC (1997) How to grow fresh air: 50 house plants that purify your home or office. Penguin Books, New York.

Wood RA, Burchett MD, Alquezar A, Orwell R, Tarran J and Torpy F (2006) The potted-plant microcosm substantially reduces indoor air VOC pollution: I. Office field-study. Water Air Soil Poll 175: 163-80.

Wood RA, Orwell R, Tarran J, Torpy F and Burchett MD (2002) Pottedplant/growth media interactions and capacities for removal of volatiles from indoor air. J Hort Sci Biotech 77: 120-29.

$\mathrm{Xu}$ Z, Wang L and Hou H (2011) Formaldehyde removal by potted plant-soil systems. $J$ Hazard Mater 192: 314-18.

Yang D S, Pennisi S V, Son K and Kays S J (2009) Screening indoor plants for volatile organic pollutant removal efficiency. Hort Sci 44: 1377-81.

Yang D S, Son KC and Kays SJ (2009) Volatile organic compounds emanating from indoor ornamental plants. Hort Sci 44: 396-400.

Yoo M H, Kays S J, Son K C and Kwon Y J (2006) Efficacy of indoor plants for the removal of single and mixed volatile organic pollutants and physiological effects of the volatiles on the plants. J American Society Hort Sci 131: 452-58.

\section{How to cite this article:}

Shraranbir Kaur Bal, Jatinderjit Kaur Gill and Akriti Sharma. 2018. Efficiency of Potted Plants in Maintaining the Quality of Indoor Air. Int.J.Curr.Microbiol.App.Sci. 7(07): 1843-1849. doi: https://doi.org/10.20546/ijcmas.2018.707.219 